\title{
The Role of Social Media for Collaborative Learning to Improve Academic Performance of Students and Researchers in Malaysian Higher Education
}
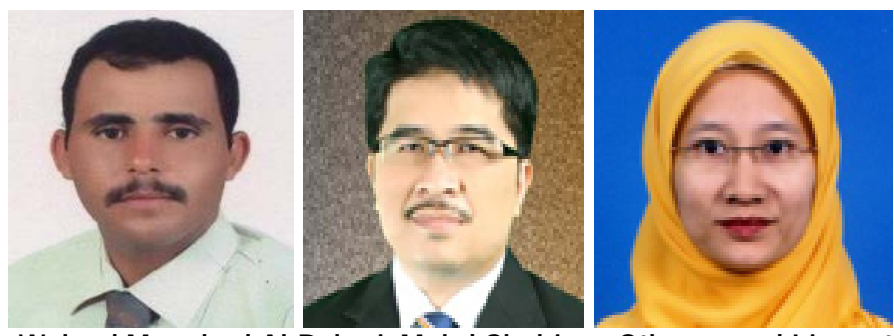

Waleed Mugahed Al-Rahmi, Mohd Shahizan Othman and Lizawati Mi Yusuf Faculty of Computing, Universiti Teknologi Malaysia

\begin{abstract}
Social media is widely considered to improve collaborative learning among students and researchers. However, there is a surprising lack of empirical research in Malaysian higher education to improve performance of students and researchers through the effective use of social media that facilitates desirable outcomes. Thus, this study offers a review of the empirical literature, and its distinctiveness stems from the focus on collaborative learning and engagement to understand the interactive factors relevant that affect academic performance. This study also explores factors that contribute to the enhancement of collaborative learning and engagement through social media. It is unique in that it highlights that the effective use of social media for collaborative learning, engagement, and intention to use social media" - a phenomenon that relies on the theory of social constructivist learning. The findings showed that collaborative learning, engagement, and intention to use social media positively and significantly relate to the interactivity of research group members with peers and research students with supervisors to improve their academic performance in Malaysian higher education.
\end{abstract}

Keywords: Social Media, Interactivity, Intention to Use, Academic Performance. 


\section{Introduction}

Malaysia, like many other countries, has been hit by the social media phenomenon. Statistics reveal that Malaysia is among the top five countries in terms of number of Facebook accounts created. Social media has infiltrated the 21st century generations of Internet users, making it a very prominent means of communications dissemination, particularly among students at the higher level of education. Consequently, academic activities in institutions and faculties are increasingly carried out through social networks, such as Facebook, Twitter, and LinkedIn. These are essentially used in order to connect with current and potential students and to deliver instructional content (Ainin, Naqshbandi, Mogavvemi, \&J aafar, 2015). Questions arise about the impact of social media on academic performance and the possibility of using it as an effective pedagogical tool to improve academic performance of students. In this regard, Zixiu, Xiongwen, Yuan, \& Yifan, (2011) used five sub-dimensions to represent the variables that are the resultant action of effective communication in students' learning. In addition, Alloway \& Alloway (2012) explain that the continuum by which people with similar interests interact and the opportunity to create, share, and exchange ideas and straight answers through the virtual network is regarded as social networking. Others consider it as an international system aiding communication (Lariscy, Avery, Sweetser \& Howe, 2009). Moreover, social networking includes other paraphernalia for social exchange such as e-mail, intranet, blogs, videoconferencing, photo discussing, wikis, and virtual mobile phone industries (Eyrich, 2008). In this study, "Facebook is examined as a specific social networking tool and in this regard, its effect on collaborative learning and its indirect impact on student's satisfaction and student's performance improvement are investigated" (Alrahmi, Othman \& Yusuf, 2015a). The overall idea is to examine the tool's aspects, which allow people to take advantage of technology and talk about content, opinions, encounters, experience, and technologies among peers by collaborative learning (Redecker, Ala-Mutka, \& Punie, 2010). However, academic performance was reported to be negatively affected by time spent on social networks (Jacobsen \& Forste, 2011; Paul, Baker, \& Cochran, 2012). Along the same line of contention, social media network has been cited to distract students from studying and to lead to academic challenges (Junco, 2012; Madge, Meek, Wellens, \& Hooley, 2009; Paul et al., 2012; Alrahmi, Othman \& Yusuf,2015a), and negative study habits (Ahmed \& Qazi, 2011).Moreover , previous frameworks of social media have many significant negative impacts on student engagement, collaborative learning, and academic performance (Cao \& Hong, 2011; J unco, 2012; Kirschner \& Karpinski, 2010). In contrast to prior studies, the present study is unique in that it examines factors affecting collaborative learning and engagement through the use of social media, and the impact of collaborative learning through social media on the academic performance in Malaysian higher education. 


\section{Effective Use of Social Media}

Social media's potential power to facilitate higher-level learning outcomes via collaborative learning appears evident and it is supported by studies in literature (Brown, 2012; J unco, Heiberger \& Loken, 2011; Novak, Razzouk, \& Johnson, 2012). Even UNESCO, in its policy document, supported the potential of social media in this regard (Kommers, 2011) and recommended classroom experimentation with it to highlight its strengths and weaknesses. The perspective of the potential effective use of collaborative learning via social media in institutions of higher learning in the present time is often referred to as Web 2.0 (O'Reilly, 2007). This provides more interaction, collaborative learning, and user modifications (Kaplan \& Haenlein, 2010) compared to Web 1.0, which is characterized as a more static resource that allows less interaction (Naik \& Shivalingaiah, 2008). In comparison to normal websites, social media has specific applications that provide various ways to collaborate. They comprise different tools elaborated by Kaplan and Haenlein (2010), which include collaborative projects (Wikipedia), blogs, content communities (YouTube), and social networking sites (Facebook). Social networking sites (SNSs) have strong academic cultures that are built within the online community (June, 2011). Social media does not merely allow knowledge transfer but it also facilitates students' collaborative learning to creating understanding among students, discussion with peers, lecturers, ilncrease knowledge sharing, and improve research students skills (Redecker et al., 2010). Surveys were administered to undergraduate and graduate students, the result significant differences were found between Facebook users and non-users for Grade Point Average (GPA) and study time (Karpinski, 2009). This notion was reflected in prior studies' (Larusson \& Alterman, 2009; Ertmer, Newby, Liu, Tomory, Yu, \& Lee, 2011) experiments involving students and Wiki's. Furthermore, according to Meyer (2010), using social media in completing assignments led to greater degrees of learning as asserted by Bloom's taxonomy, particularly in online discussions. Evidence was also found for the potential contributions of Twitter, a microblogging tool (J unco et al., 2011) and social annotation tools to collaborative learning (Novak et al., 2012).

\section{Conceptual Framework and Hypotheses}

This study proposes a framework for the impact of social media use on collaborative learning among researchers at five research universities in Malaysian higher education, based on the constructivism theory (Vygotsky, 1978); see Figure 1, "The research framework with hypotheses." The present study revealed that social media integration is linked to collaborative learning among students, with social media variables such as interactivity with research group members (GM), interactivity with supervisors (SU), engagement (EN), collaborative learning (CL) researchers' satisfaction (RS) and performance of the researchers (AP). This study has twelve hypotheses; see Figure 1 and Table 5:

This work is licensed under a Creative Commons Attribution 4.0 International License. 


$\begin{array}{llllllll}\text { H1 } & \text { Hypothesis one } & \text { H2 } & \text { Hypothesis tow } & \text { H3 } & \text { Hypothesis three } & \text { H4 } & \text { Hypothesis four } \\ \text { H5 } & \text { Hypothesis five } & \text { H6 } & \text { Hypothesis six } & \text { H7 } & \text { Hypothesis seven } & \text { H8 } & \text { Hypothesis eight } \\ \text { H9 } & \text { Hypothesis nine } & \text { H10 } & \text { Hypothesis ten } & \text { H11 } & \text { Hypothesis eleven } & \text { H12 } & \text { Hypothesis twelve }\end{array}$

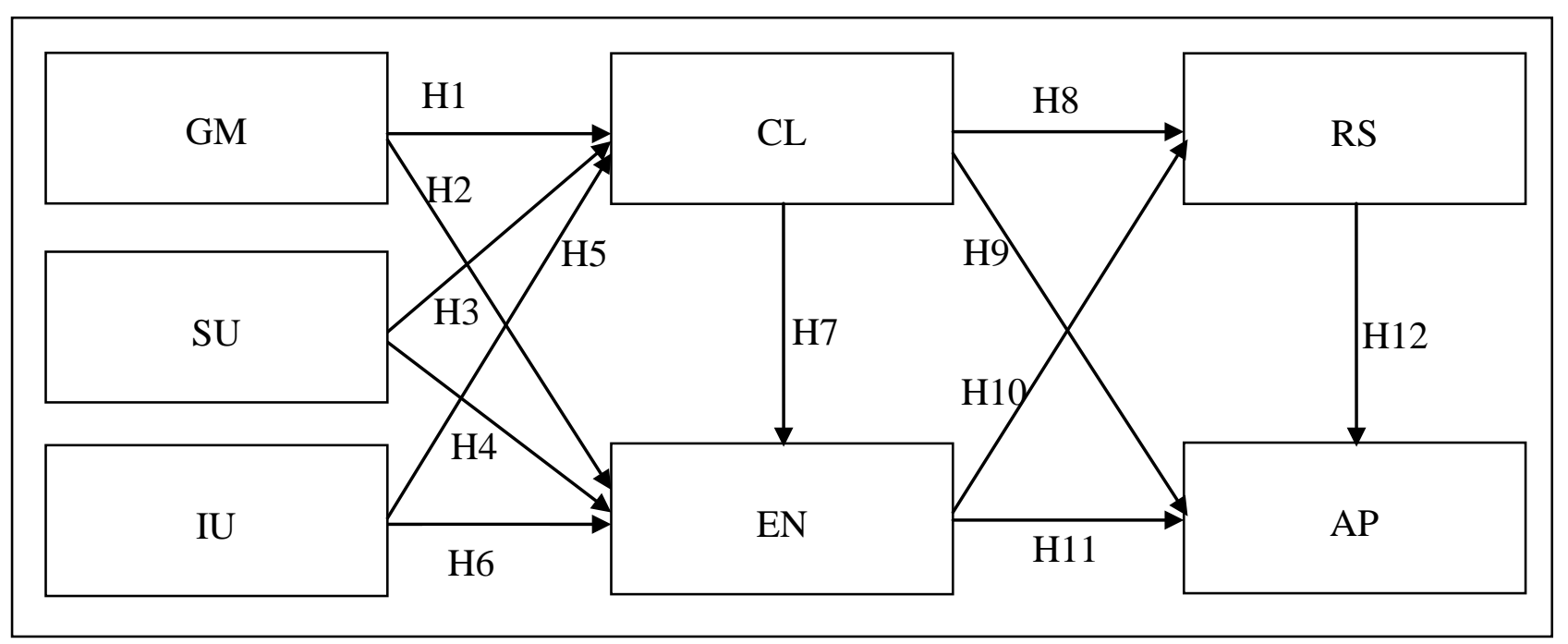

Figure 1. The research framework with hypotheses

\section{Social Media Use and Interactivity with Group Members and Peers}

Social media facilitates collaboration, contributes to the relationship development among students, and provides instantaneous opportunities for curricula dissemination and enhancement that is external to the actual classroom (Fewkes \& McCabe, 2012; J unco et al., 2012; Top, 2012). Using social media in school related activities, such as discussions, enables students' subject discussion and content interaction (Patera, Draper, \& Naef, 2008). This single location communication paves the way for conversations that are needed and increases the potential of higher students learning that goes beyond the topic brought up by the moderator or the instructor (Hurt et al., 2012; Al-Rahmi \& Othman, 2013a; Al-Rahmi et al., 2014). In a related study Liu, Liu, Chen, Lin, \& Chen (2011) contend that social media's encouragement and generation of information sharing call for the understanding of it as a tool, and by providing students with the virtual community experience, they can comprehend the content and create networks via different sources (Frye, Trathen, \& Koppenhaver, 2010). This opportunity paves the way to 
several opportunities that heightens enhance student learning through interactivity. On the basis of the above discussion, the following hypotheses are proposed;

H1: There is a significant relationship between interactivity among student group members and collaborative learning.

H2: There is a significant relationship between interactivity among student group members and engagement.

\section{Social Media Use and Interactivity with Supervisors and Lecturers}

Lecturers and supervisors using social media should be able to play an active role in collaboration with students. This is because it is their responsibility to promote student's creativity, assess activities, and explain misunderstanding arising from the content area and knowledge creation in order to sustain the learning environment integrity (Frye et al., 2010; Liu, 2011). Some lecturers as well as supervisors have identified methods to integrate social media in their lectures and curricula while others are not willing to use it (Fewkes \& McCabe, 2012). However, social media use should be purposeful and it should be employed in circumstances that are suitable for learning, where researchers and students' understanding can happen (Liu, 2011). Social media can be optimally used as an introductory review and collaborative learning tool and not just as an advertising method for class reminders (Fewkes \& McCabe, 2012; Al-Rahmi \& Othman, 2013a; and Al-Rahmi et al., 2014; 2015). Hence, lecturers and supervisors looking to incorporate social media in their instruction methods should make sure that the certain social media type used is aligned with the learning outcomes in order to improve academic performance. Chen (2015) has shown that participants with "Assimilating" and "Diverging" learning styles performed better than those with "Accommodating" and "Converging" learning styles as social networking sites such as Facebook, which have become popular, have the potential to function as an educational tool enabling peer feedback, interaction, and learning in a social context. Lecturers and supervisors desirous of using social media in their academic courses for the promotion of student learning have to be prepared to support students in their learning, and to play a significant role in facilitating a collaborative learning community. To assume that students readily know the way around social media may negatively impact those who are less familiar with it and who still need supervision and guidance (J ackson, 2011; Valjataga \& Fiedler, 2009; Al-rahmi et al., 2015c). It is also crucial for educators to acknowledge the potential for distractions and over-stimulation of some specific social media types (Chen \& Bryer, 2012; Patera et al., 2008). Based on the above, the researcher proposes the following hypotheses;

H3: There is a significant relationship between interactivity with supervisors and collaborative learning.

H4: There is a significant relationship between interactivity with supervisors and engagement. 


\section{Intention towards Using Social Media}

Students' intention to use social media network in collaborative learning is the key factor in structure technology utilization models (Venkatesh, Morris, Davis, \& Davis, 2003; Davis, Bagozzi, $\&$ Warshaw, 1989). All these theories/models are extended from the basic principles of TRA, which posits that intention to use the system is the function of attitude towards individual behavior and subjective norms. This was later expanded to include intention to use and hence TPB theory (Venkatesh \& Bala, 2008). Perceived enjoyment is considered as an important user's post-adoption belief that leads to increased levels of user satisfaction and continuance intention (Pelling \& White, 2009). According to Moon \& Kim (2001), individuals who enjoy a web system will positively view their interactions with the system and in turn, display high intention to use it to improve their collaborative learning (Al-rahmi et al.,2015b; Al-Rahmi et al., 2014; Sanchez, Cortijo \& Javed, 2014; Al-Rahmi \& Othman, 2013b). Considering the above discussion, the researcher proposes that;

H5: There is a significant relationship between intention to use social media and collaborative learning.

H6: There is a significant relationship between intention to use social media and engagement.

\section{Social Media Use and Collaborative Learning}

Shoshani and Braun (2007) claim that collaborative learning supports social media and eventually, creative learning. Collaborative learning comprises the interactions and connections of the student with the curricula. In this scenario, social media enables the extension of the learning environment because only a part of learning takes place in classes (Chen \& Bryer, 2012; Friesen \& Lowe, 2012; Wodzicki, Schwämmlein, \& Moskaliuk, 2012; Al-rahmi et al., 2015a). Therefore, it is crucial for educators to determine the effective methods that can assist in integrating social media into classes (Fewkes \& McCabe, 2012). They can make use of social media to boost students' creativity and exploration of curricula content (Frye et al., 2010; Lamb \& J ohnson, 2010). Social media provides various alternatives to the development of actual products via blogs, YouTube and even podcasts and it also enables the exploration of content material in new knowledge generation (Frye et al., 2010; Lamb \& Johnson, 2010; Al-Rahmi, \& Othman, 2013a; and Al-Rahmi et al., 2014; 2015). By satisfying the creative learners' need with cooperative learning, they will be more able to balance their individualism and peer connection, and this ultimately results in ideas creation (Garrett, 2011; Shoshani \& Braun, 2007). Considering the above discussion, the researcher proposes that;

H7: There is a significant relationship between collaborative learning and engagement. 
H8: There is a significant relationship between collaborative learning and researcher's satisfaction.

H9: There is a significant relationship between collaborative learning and academic performance.

\section{Social Media Use and Engagement}

Engagement, in the context of social media, results in a learning environment characterized by greater collaboration and communication brought about by peer discussion and interactions (Heafner \& Friedman, 2008; J ackson, 2011; Liu et al., 2011). Additionally, prior studies (Arnold \& Paulus, 2010; Dawson, 2008; Hurt et al., 2012; Al-Rahmi et al., 2014; Top, 2012) contended that social media opens the doors to developing a higher sense of student community via collaboration among peers on certain topics. Moreover, social networking sites (SNSs), social capital, and psychological well-being offer an additional link to student learning through the mechanism of academic engagement, and increase engagement with school and academics (J une, 2011). On the one hand, students who enjoy their experience become highly engaged with the social media, which is often viewed positively by students and researchers, and technology providers. Turel and Serenko, (2012) suggest that enjoyment can lead to presumably positive outcomes, such as high engagement. More specifically, Dawson (2008) claimed that the degree of students' perception of community may be influenced by the presence of social networks, where students communicating with many peers feel a higher sense of community. Using social media also offers a sense of community among students by providing them a chance to personalize their profiles, add pictures and specific personal information as contended by Arnold and Paulus (2010), Stevens (2009), and Al-Rahmi and Othman (2013a). Moreover, Facebook enables students who are not active to increase their participation in learning activities (Meishar-Tal, Kurtz \& Pieterse, 2012). Such personalization and examination of curriculum support an actual connection among students by encouraging their information sharing and ultimately this leads to their perceived learning (Hurt, Moss, Bradley, Larson, Lovelace, Prevost \& Camus, 2012; Top, 2012). Furthermore, Elsweiler and Harvey (2014) suggested that Twitter search is primarily a device for mental and social engagement and a means to stay informed in a dynamic information world and it is this social dynamism that makes this new source of information quite different to those of the earlier web. On a final note, the collaboration of researchers with peers with the help of social media may facilitate a creative learning environment and thus the following hypotheses are proposed;

H10: There is a significant relationship between engagement and researchers satisfaction.

H11: There is a significant relationship between engagement and academic performance. 


\section{Social Media Use and Satisfaction of Students and Researchers}

Using social networking in higher education guarantees sufficient understanding transfer and contributes to student learning performance improvement (Vie, 2008). Evaluative periods were articulated as a way of feedback process between instructor-student in literature (i.e. Foroughi, 2011; Al-Rahmi \& Othman, 2013c) to determine the level of students' understanding, satisfaction, and students' academic performance outcome. Additionally, records showed that the adoption of social networking triggers positive association between students' academic performance and their satisfaction (Cao \& Hong, 2011; Al-rahmi et al., 2015a; Al-rahmi et al., 2015b).

Based on Ajjan and Hartshorne (2008) and Al-Rahmi et al. (2014) reported findings, there is a significant association between student learning performance and student satisfaction with learning through the usage of social networking as a platform for collaborative learning process. Some faculty officials believe that certain social networking tools could improve students' learning, their interaction with faculty and other peers, their writing capabilities, as well as their satisfaction and learning performance. Therefore, the following hypothesis is proposed;

H12: There is a significant relationship between researchers' satisfaction and academic performance.

\section{Social Media Use and Academic Performance of Students and Researchers}

Students taking advantage of social media incorporated in class, display higher relationship with their peers in comparison to their counterparts who are not (Annetta, Minogue, Holmes \& Cheng, 2009; J ackson, 2011; Tomai et al., 2010). According to studies (J ackson, 2011; Mazman \& Usluel, 2010; Wodzicki et al., 2012), students are enabled by social media to categorize themselves with similar peers and to enhance and connect with them. Moreover, it also decreases the diversity in the classroom via a neutral zone wherein students can interact with their peers (J unco et al., 2011; Pike, Kuh, \& McCormick, 2011; Al-rahmi et al., 2014). More importantly, students leveraging social media feel emotional connection with their peers as they feel that they may take help from them in case they need to. These peer linkage encourages the participation of all students, specifically those who are hesitant to discuss matters face-to-face (Arnold \& Paulus, 2010; J unco et al., 2011; Rambe, 2008).

\section{Methodology}

This study aims to answer the question, "What is the relationship between researchers and supervisors through collaborative learning and engagement by social media use?" The next sections provide description on the methods used to answer the above question. The data for the 
analysis was gathered through a survey questionnaire distributed to 741 postgraduate students in the 2013/2014 academic session to obtain information about their experiences and the impact of using social media on collaborative learning through constructivism theory. The present study uses a five-point Likert scales for measuring all variables, from 1-5: (1) Strongly disagree, (2) Disagree, (3) Undecided, (4) Agree, (5) Strongly Agree. The selection and construction of a measurement scale requires the consideration of several factors that influence the reliability, validity, and practicality of the scale (Cooper \& Schindler, 2006).The respondents were required to offer information of their experiences in using social media tools for collaborative learning and engagement to improve their performance. From the distributed questionnaires within threemonth duration, questionnaires were found 18 incomplete, thus, 723 valid responses were returned. The IBM SPSS (Version-20) and Amos (Version-16) were used to analyze the data.

\section{Sample}

Two types of sampling techniques are cited in literature namely random sampling and nonrandom sampling. Sampling is described as a statistical procedure involving the selection of subset of individual observations from a population, intending to generate an effective knowledge concerning the students in Malaysian higher institutions. The first type is selected for the present study as it offers the target population equal chances to be selected. Therefore, the sample comprised of randomly selected postgraduate students who belong to five research universities in Malaysia namely UM, UKM, USM, UTM and UPM. According to Krejcie and Morgan (1970) sampling table, the number of respondents was gauged to be seven hundred and twenty-three (723).

\section{Data Collection and Measurement}

This study is part of a larger study that examines the researchers' opinions about the use of social media for collaborative learning and engagement to improve their performance, and the underlying theory employed is the constructivism theory. The study questionnaire consisted of open-ended and close-ended survey questions. The questionnaires consist of 21 questions pertaining to background information, the intention to use social media, researchers' perception on social media tools for collaborative learning, and the influence on performance of the researchers. The questions aimed to measure the students and researchers' perceptions of social media use and its influence on their academic performance. With regards to the measurement of constructs, interactivity with group members and supervisors was measured using a subset of three items from Liu et al., (2003) and McMillan and Hwang (2002), engagement was measured using three items adapted from Gallini and Moely (2003), collaborative learning was measured using three items adapted from So and Brush (2008), intention to use social media was measured using three items from (Kim, 2011), researchers' satisfaction was measured using three items 
adapted from (Moore, 2009) and finally, students' academic performance was measured using three items adapted from (MacGeorge et al., 2008; Banks, 2006). See Table 1:

Table 1

Constructs, Items, and Confirmatory Factor Analysis Results

\begin{tabular}{lllllll}
\hline Constructs and items & FL & (CR) & (AVE) & Alpha \\
& & $(>.50)$ & $(>.70)$ & $(>.50)$ & $(>$ \\
& & & & & $.70)$
\end{tabular}

Interactivity with group member (Liu et al., 2003; McMillan

\& Hwang, 2002 )

Using Social media in class...

GM1. Facilitates interaction with group member

GM2. Gives me the opportunity to discuss with group member $\begin{array}{llll}0.887 & 0.757 & 0.532 & 0.884\end{array}$

GM3. Allows the exchange of information with group member

Interactivity with supervisor (Liu et al., 2003; McMillan \& Hwang, 2002 )

Using Social media in class...

SU1. Facilitates interaction with the supervisor

SU2. Gives me the opportunity to discuss with the supervisor 0.783 $\begin{array}{llll}0.862 & 0.844 & 0.645 & 0.734\end{array}$

SU3. Allows the exchange of information with the supervisor

$$
0.761
$$

Collaborative learning (So \& Brush, 2008)

In this course...

CL1. I felt that I actively collaborated in my learning 0.689 experience 
CL2. I felt that I have co-created my own learning experience

0.673

0.715

0.500

0.809

CL3. I felt that I had free reign to co-create my own learning experience

Engagement (Gallini \&Moely, 2003 )

Using Social Media ...

EN1. I felt that my opinions have been taken into account in this course

EN2. In this course, my peer and faculty interactions made me feel valuable

EN3. This course has favored my personal relationships with $\begin{array}{llll}0.842 & 0.782 & 0.549 & 0.800\end{array}$ my group member and supervisor

\subsection{8}

Intention to Use Social Media ( Kim, 2011)

IU1. I intend to keep on use of social media to collaborative and engagement

IU2. I intend to recommend my friends to using of social media in the future

IU3. I intend to use social media to improve my research skills
0.805
0.741
0.520
0.765

0.616

Researchers' Satisfaction ( Moore, 2009)

RS1. I enjoy the experience of collaborative learning with group member

\subsection{2}

RS2. I enjoy the experience of collaborative learning with supervisor
0.763
0.762
0.519
0.755

RS3. I satisfied with the collaborative and engagement by social media use 


\subsection{8}

Academic Performance ( (MacGeorge et al., 2008; Banks, 2006)

The use of Social Media...

AP1. Has improved my comprehension of the concepts studied

$\begin{array}{llll}0.726 & 0.708 & 0.507 & 0.790\end{array}$

AP2. Has led to a better learning experience in this module

AP3. Has allowed me to better understand the concepts in this $\quad 0.672$ module

Note: FL: factor loading; CR: composite reliability; AVE: average variance extracted and Alpha:cronbach's alpha.

Table 2

Discriminant Validity

\begin{tabular}{llllllll}
\hline & RS & GM & SU & IU & CL & EN & AP \\
\hline RS & $\mathbf{0 . 7 2 0}$ & & & & & \\
GM & 0.404 & $\mathbf{0 . 7 3 0}$ & & & & \\
SU & 0.362 & 0.357 & $\mathbf{0 . 8 0 3}$ & & & & \\
IU & 0.554 & 0.306 & 0.264 & $\mathbf{0 . 7 0 1}$ & & & \\
CL & 0.604 & 0.481 & 0.444 & 0.390 & $\mathbf{0 . 6 7 7}$ & & \\
EN & 0.412 & 0.429 & 0.453 & 0.383 & 0.599 & $\mathbf{0 . 7 4 1}$ & \\
AP & 0.611 & 0.450 & 0.477 & 0.483 & 0.612 & 0.520 & $\mathbf{0 . 6 7 0}$
\end{tabular}

Note: RS: Researchers' Satisfaction; GM: Interactivity with Group Member; SU: Interactivity with Supervisor; IU: Intention to Use; CL: Collaborative learning; EN: Engagement and AP: Academic Performance. 
Discriminant validity in this study was evaluated by three criteria; correlation index among variables is less than 0.80 (Hair et al., 2010), value of the average variance extracted (AVE) of each construct is equal to or greater than 0.5 (Hair et al., 2010), and square root AVE of each construct is higher than inter-construct correlations (IC) associated with that factor (Fornell \& Larcker, 1998). Moreover, the constructs, items and confirmatory factor analysis results factor loading of 0.5 or greater is acceptable, Cronbach's Alpha $\geq 0.70$; Composite Reliability $\geq 0.70$ (Hair et al., 2010).

\section{Result and Discussion}

The respondents' background information was obtained through the questionnaire and the result of the analysis is presented in Table 3. The distribution of respondents on the basis of demographic characteristics of the sample is as follows; the categorization of respondents based on gender is - 329 male respondents corresponding to (45.5\%) and 394 female respondents (54.5\%). From the number of respondents, it is evident that the number of female respondents is higher than male respondents. This was not deliberately done by the researcher. Secondly, based on their ages, the respondents are categorized as follows; 96 respondents (13.3\%) came from 2124 years old group, 305 respondents (42.2\%) came from 25-30 years old group, 192 respondents (26.6 \%) fell into the 30-35 years old group and 130 respondents (18.0\%) were above 35 years old. In addition, the majority of the respondents were $\mathrm{PhD}$ students the number of respondents based on their degree of researchers, which are 103 respondents (14.3\%) are master full research students, 121 respondents (16.8\%) are master mixed mode students, 104 respondents (14.5\%) master taught course, 391 respondents (54.4\%) come from $\mathrm{PhD}$ research students. Finally, the distribution of respondents based on the use of social media is; 687 respondents (95.0\%) came from the students and researchers currently using social media network, 36 respondents (5.0\%) came from the students and researchers who used social media before but not presently.

Table 3

Number of Respondents Based On Gender, Age and Degree of Researchers

\begin{tabular}{llllll}
\hline $\begin{array}{l}\text { Demographi } \\
\text { c factors }\end{array}$ & Categories & Frequency & Percent & $\begin{array}{l}\text { Valid } \\
\text { Percent }\end{array}$ & $\begin{array}{l}\text { Cumulative } \\
\text { Percent }\end{array}$ \\
\hline Gender & Male & 329 & 45.5 & 45.5 & 45.5 \\
& Female & 394 & 54.5 & 54.5 & 100.0 \\
\hline
\end{tabular}




\begin{tabular}{|c|c|c|c|c|c|}
\hline & Total & 723 & 100.0 & 100.0 & \\
\hline \multirow[t]{5}{*}{ Age } & $21-24$ & 96 & 13.3 & 13.3 & 13.3 \\
\hline & $25-30$ & 305 & 42.2 & 42.2 & 55.5 \\
\hline & $30-35$ & 192 & 26.6 & 26.6 & 82.0 \\
\hline & Above 35 & 130 & 18.0 & 18.0 & 100.0 \\
\hline & Total & 723 & 100.0 & 100.0 & \\
\hline \multirow[t]{5}{*}{ Education } & Master Full Research & 103 & 14.3 & 14.3 & 14.3 \\
\hline & Master Mixed Mode & 121 & 16.8 & 16.8 & 31.1 \\
\hline & Master Course & 104 & 14.5 & 14.5 & 45.6 \\
\hline & $\mathrm{PhD}$ & 391 & 54.4 & 54.4 & 100.0 \\
\hline & & 723 & 100.0 & 100.0 & \\
\hline \multirow[t]{4}{*}{$\begin{array}{l}\text { Use of social } \\
\text { media }\end{array}$} & $\begin{array}{l}\text { Currently using social } \\
\text { media network. }\end{array}$ & & & & \\
\hline & $\begin{array}{l}\text { Have used it but do not } \\
\text { use it anymore. }\end{array}$ & 687 & 95.0 & 95.0 & 95.0 \\
\hline & Total & 36 & 5.0 & 5.0 & 100.0 \\
\hline & & 723 & 100.0 & 100.0 & \\
\hline
\end{tabular}

The relationship between performance of the researchers with collaborative learning and engagement to use social media were measured through interactivity with research group members, interactivity with supervisor and intention to use social media. In this regard, the reliability coefficient of Cronbach's Alpha based on standardized items was found to be 0.874 . 


\section{Measurement Model Analysis}

Structural equation modelling (SEM) was employed as the main statistical technique to analyze data with confirmatory factor analysis (CFA) using Amos 16. The overall goodness-of-fit was assessed using fit Indices ( $\mathrm{X}^{2}, \mathrm{df}, \mathrm{X}^{2} / \mathrm{df}, \mathrm{RMR}, \mathrm{IFI}, \mathrm{TLI}, \mathrm{CFI}$ and RMSEA). The initial confirmatory factor analysis showed an acceptable overall model fit. The goodness fit indices to measurement model all values were acceptable the measurement model results are shown in Table 4.

Table 4

Summary of Goodness Fit Indices

\begin{tabular}{|c|c|c|}
\hline Type of Measure & Acceptable Level of Fit & Value \\
\hline Chi-square ( $\left.\chi^{2}\right)$ & $\leq 3.5$ to $o$ (perfect fit) and $(\rho>.01)$ & 2541.302 \\
\hline Normed Chi-square ( $\chi 2)$ & Value should be greater than 1.0 and less than 5.0 & 2.107 \\
\hline Root-Mean Residual (RMR) & Close to 0 (perfect fit) & .033 \\
\hline Incremental Fit Index ( IFI) & Value should be equal to or greater than 0.90 . & .952 \\
\hline Tucker Lewis Index (TLI) & Value should be equal to or greater than 0.90 . & .949 \\
\hline Comparative Fit Index (CFI) & Value should be equal to or greater than 0.90 . & .953 \\
\hline \multirow[t]{2}{*}{$\begin{array}{l}\text { Root mean square error of } \\
\text { approximation (RMSEA) }\end{array}$} & $\begin{array}{l}\text { Value below } 0.10 \text { indicates a good fit and below } 0.05 \text { is } \\
\text { deemed a very good fit. }\end{array}$ & \\
\hline & & .036 \\
\hline
\end{tabular}

Source: Adapted from (Hair et al., 2010)

\section{Structural Model Analysis}

In the next step of the structural equation model (SEM), the researchers ran CFA to test structural framework. Table 5 shows the structural framework and from the table, it can be clearly seen that the model's key statistics are very good indicating a valid framework and the suitability to test the proposed hypotheses. 


\section{Results of Hypothesis Testing}

The results of this research provided support for the framework and for the hypotheses regarding the directional linkage between the framework's variables. The parameters of unstandardized coefficients and standard errors of the structural framework are shown in Table 5.

Table 5

Regression Weights

\begin{tabular}{|c|c|c|c|c|c|c|c|c|}
\hline $\mathbf{H}$ & Independent & Relationship & Dependent & Estimate & S.E. & C.R. & $\mathbf{P}$ & Result \\
\hline H1 & $\mathrm{GM}$ & $\longrightarrow$ & CL & .168 & .037 & 4.556 & $* * *$ & Supported \\
\hline H2 & GM & & EN & .239 & .032 & 7.547 & $* * *$ & Supported \\
\hline H3 & SU & & CL & .214 & .028 & 7.641 & $* * *$ & Supported \\
\hline H4 & SU & & EN & .135 & .025 & 5.492 & $* * *$ & Supported \\
\hline H5 & IU & $\longrightarrow$ & CL & .403 & .038 & 10.587 & $* * *$ & Supported \\
\hline H6 & IU & & EN & .166 & .035 & 4.802 & $* * *$ & Supported \\
\hline H7 & $\mathrm{CL}$ & & EN & .330 & .031 & 10.502 & $* * *$ & Supported \\
\hline H8 & $\mathrm{CL}$ & & RS & .315 & .032 & 9.688 & $* * *$ & Supported \\
\hline H9 & CL & & $\mathrm{AP}$ & .272 & .034 & 8.032 & $* * *$ & Supported \\
\hline H10 & EN & & RS & .287 & .034 & 8.369 & $* * *$ & Supported \\
\hline H11 & EN & & $\mathrm{AP}$ & .194 & .035 & 5.519 & $* * *$ & Supported \\
\hline H12 & $\mathrm{RS}$ & & $\mathrm{AP}$ & .367 & .036 & 10.323 & $* * *$ & Supported \\
\hline
\end{tabular}

C.R.: Critical Ratio or t-value

The table above (Table 5) and the figure below (Figure 2) indicate that intention to use social media positively and significantly related with collaborative learning $(\beta=0.403, p<0.001)$. Thus, hypothesis $\mathrm{H} 5$ that proposed a significant relationship between intention to use social media and 
collaborative learning is supported indicating the impact of social media on the engagement between research group members and the supervisor.

The findings in Table 5 also shows that satisfaction of students and researchers positively and significantly related with their academic performance $(\beta=0.367, \mathrm{p}<0.001)$. Hence, hypothesis H12 that proposed a significant relationship between satisfaction of students and researchers and their academic performance is supported. This indicates that discussions with group member or supervisors through social media's collaborative learning improve the academic performance of students and researchers. The findings in Table 5 also confirmed that collaborative learning positively and significantly related with students and researchers' engagement $(\beta=0.330, p<$ 0.001) indicating that hypothesis $\mathrm{H} 7$ that proposed a significant relationship between collaborative learning and engagement to improve academic performance of students and researchers when using social media is supported. Next, hypothesis eight was also supported in its proposition that collaborative learning positively and significantly related with satisfaction of students and researchers $(\beta=0.315, \mathrm{p}<0.001)$. This shows that exchange of information with group members increases the knowledge sharing capabilities and facilitates discussion among research group members and peers. The findings also showed that engagement positively and significantly related with satisfaction of students and researchers $(\beta=0.287, \mathrm{p}<0.001)$. Hence, hypothesis $\mathrm{H} 10$ was supported as it proposed a significant relationship between engagement and satisfaction of students and researchers. This reveals the students and researchers' satisfaction when engaging with their group members and supervisors or lecturers.

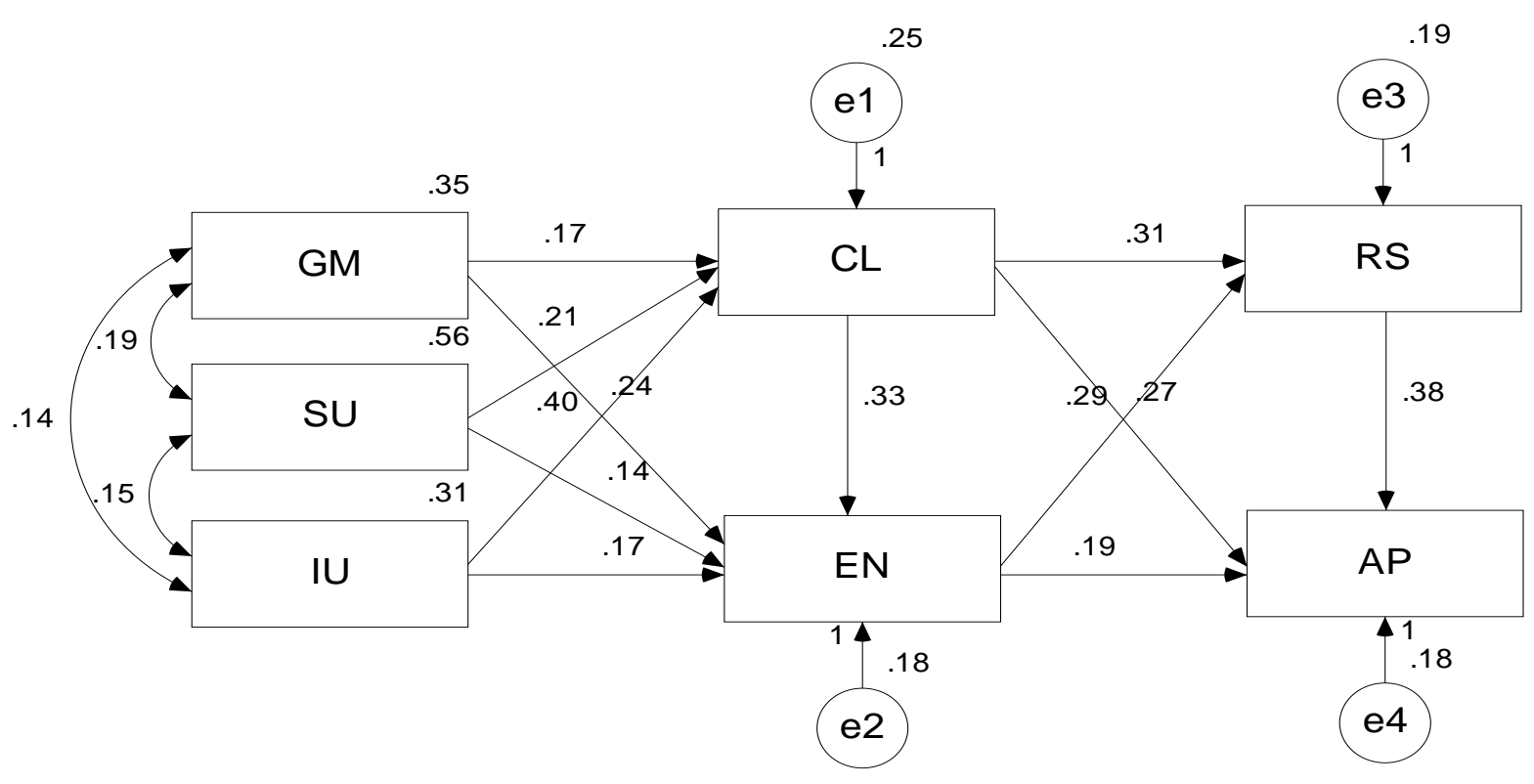

Figure 2. Results of the proposed framework

This work is licensed under a Creative Commons Attribution 4.0 International License. 
Table 5 also reveals that collaborative learning positively and significantly related with academic performance of students and researchers $(\beta=0.272$, $p<0.001)$ and thus supporting hypothesis H9 that proposed a significant relationship between collaborative learning and academic performance of students and researchers. Thus, the students and researchers learn how to work with others effectively through collaborative learning brought about by social media. The findings also confirmed that interactivity with research group members and peers positively and significantly related with engagement $(\beta=0.239, \mathrm{p}<0.001)$. Hence, hypothesis $\mathrm{H} 2$ that proposed a significant relationship between interactivity with research group members and engagement in social media. Thus, social media allows the exchange of information with lecturers and facilitates discussion with supervisors. Along the same line of results, interactivity with supervisors was found to significantly relate to collaborative learning $(\beta=0.214, p<0.001)$ indicating support for the third hypothesis. It can thus be stated that actively developing problem solving skills with supervisors through social media facilitates discussion with them.

Furthermore, the results showed that engagement positively and significantly related with academic performance of students and researchers $(\beta=0.194, p<0.001)$ and this result supports hypothesis H11. Hence, academic performance of students and researchers improves when they engage and share information and knowledge with research group members and supervisors or lecturers through social media. The next result confirmed that interactivity with research group members positively and significantly related with collaborative learning through social media ( $\beta=$ 0.168, $\mathrm{p}<0.001$ ). Thus, hypothesis $\mathrm{H} 1$ that proposed a significant relationship between interactivity with research group members and collaborative learning is supported. Therefore, researchers need to share their ideas and knowledge with the members of their research group. Also, hypothesis H6 was confirmed as the results showed that intention to use social media positively and significantly related with engagement $(\beta=0.166, p<0.001)$. In other words, researchers need intention to use social media to improve their engagement with research group members, supervisors, or lecturers. The final hypothesis, hypothesis four was also confirmed as the result showed that interactivity with supervisor or lecturers positively and significantly related with engagement $(\beta=0.135, p<0.001)$ although the level of significance is low.

\section{Analysis and Discussion}

Table 6 shows that the Pearson correlation coefficient is at 99\% confidence level. The best correlation was found between the relationship between satisfaction of students and researchers with their academic performance, and the relationship between engagement and collaborative learning with both having correlation coefficients of 0.806. The characters in tables three and four are representatives of; interactivity with research group members (GM), interactivity with 
supervisor (SU), intention to use social media (IU), collaborative learning (CL), engagement (EN), researchers' satisfaction (RS) and performance of the researchers (AP).

Table 6

Descriptive statistics and correlation matrix

\begin{tabular}{|c|c|c|c|c|c|c|c|}
\hline & $\mathbf{G M}$ & SU & IU & CL & EN & RS & $\mathbf{A P}$ \\
\hline GM & 1 & & & & & & \\
\hline SU & $.633^{* *}$ & 1 & & & & & \\
\hline IU & $.636^{* *}$ & $.551^{* *}$ & 1 & & & & \\
\hline CL & $.625^{* *}$ & $.650^{* *}$ & $.715^{* *}$ & 1 & & & \\
\hline EN & $.728^{* *}$ & $.685^{* *}$ & $.698^{* *}$ & $.806^{* *}$ & 1 & & \\
\hline RS & $.625^{* *}$ & $.575^{* *}$ & $.794^{* *}$ & $.751^{* *}$ & $.731^{* *}$ & 1 & \\
\hline $\mathbf{A P}$ & $.664^{* *}$ & $.665^{* *}$ & $.756^{* *}$ & $.794^{* *}$ & $.751^{* *}$ & $.806^{* *}$ & 1 \\
\hline
\end{tabular}

The results of Pearson correlation shows that the dependent variable (performance of the researchers) positively and significantly correlated with researchers' satisfaction $(\mathrm{r}=0.806, \mathrm{P}<$ 0.01 ), and academic performance of students and researchers positively and significantly correlated with collaborative learning $(r=0.794, \mathrm{P}<0.01)$. Positive and significant correlations were also found between performance of the researchers and intention to use social media ( $\mathrm{r}=$ 0.756, $\mathrm{P}<0.01)$, academic performance of students and researchers, and engagement $(r=0.751$, $\mathrm{P}<0.01$ ), academic performance of students and researchers, and interactivity with supervisors $(\mathrm{r}=0.665, \mathrm{P}<0.01)$ and finally, academic performance of students and researchers and interactivity with research group members $(r=0.664, \mathrm{P}<0.01)$ and finally, academic performance of students and researchers with itself has correlation.

These results indicated that interactivity with research group members, their interactivity with their supervisors, intention to use social media and their satisfaction affect academic performance 
of students and researchers. All of the above enhances the academic performance of students and researchers through collaborative learning and engagement. In general, the use of social media provides collaborative learning and engagement that are useful for postgraduate students and researchers and the use of social media in the research group would enable the researcher to accomplish tasks more quickly and using the social media enhances research effectiveness. Also, social media will be easy to incorporate in the research group as its use makes it easy to reach group members. So, the satisfaction of students and researchers about using social media for collaborative learning to improve their academic performance is high. Additionally, social media use in collaborative learning improves academic performance of students and researchers as it facilitates high interaction with supervisors, enhances communication skills and allows the exchange of information among researchers and supervisors or lecturers. The collaborative learning and engagement through social media use facilitates the researchers' intention to use social media as it makes them confident enough to presenting their work through social media brought about by such collaboration. This also makes it easy for researchers to obtain relevant resources, information and knowledge. The students and researchers were able to develop research skills through members' collaboration and exchange ideas with group members. Students and researchers will be more inclined to use social media to obtain resources from supervisor and lecturers, as it has effective functionalities like academic activities, and to coordinate with other researchers, to improve the research skills, to build researcher - supervisor relationship and ultimately, to improve academic performance.

In this research all hypotheses have accepted this contradicts most past studies which have reported that usage of social media have negatively impact an academic performance (J unco, 2012; Kirschner \& Karpinski, 2010; Madge et al., 2009). But other studies provided evidence of a positive impact on student achievement, noting that the majority of students reported positive in their courses including increased collaboration and exchange of information compared to face-toface courses (Ainin et al., 2015; Al-rahmi et al., 2015; Al-rahmi et al., 2014; Alloway \& Alloway, 2012). Even though social media has the potential to enhance the learning experience, its use has not made significant inroads into classroom usage; according to some authors, faculty members are reluctant to incorporate this technology into their teaching strategies (Roblyer, McDaniel, Webb, Herman, \&Witty, 2010; Ajjan \& Hartshorne, 2008). Nevertheless, the majority of students in our research stated that they would not mind using social media for collaborative learning and engagement as a learning tool 687 (95\%); they believe it is a useful resource that would give them the opportunity to communicate with classmates (collaborative learning and engagement), and 36 (5\%); they have used it but do not use it anymore.

Based on the conclusions of our research, we recommend encouraging students and lecturers to use social media such as Facebook and Blog. It is easy to get university learning resources online. Students and lecturers should take advantage of the social nature of social media to increase the collaborative, engagement, and communication of the learning process. However, it is essential to analyze how students and researchers use this technology and understand how the social 
dimension of social media can enhance their academic performance. Equally important would be to show lecturers the potential of social media to improve the learning experience and increase the productivity of academic activities.

\section{Conclusion and Future Work}

The present study's framework is based on the constructivist theory to improving collaborative learning and engagement through the interaction of research group members, interaction with lecturers or supervisor, and intention to use social media. Social media can assist in enhancing academic performance of students and researchers when lecturers and supervisors integrate social media in their teaching methods. The findings showed that social media facilitates collaborative learning and engagement and this improves the academic performance of students and researchers, Moreover, future studies are advised to include additional elements to measure factors influencing academic performance of students and researchers via collaborative learning and engagement in Malaysian higher education.

\section{Acknowledgements}

This material is based upon work supported by The World Academy of Sciences (TWAS), Research Grant Agreement (RGA), under No: 14-317 RG/ITC/AS_C-- UNESCO FR: 3240283418.Also supported by Faculty of Marine, Hudaidah University, Hudaidah, Yemen.

\section{References}

Ainin, S., Naqshbandi, M. M., Mogavvemi, S., \&J aafar, N. I. (2015). Facebook usage, socialization and academic performance. Computers \& Education. 83, 64-73.

Ahmed, I., \& Qazi, T. (2011). Deciphering the social costs of social networking sites (SNSs) for university students. African J ournal of Business Management, 5(14), 5664-5674.

Ajjan, H., \& Hartshorne, R. (2008).Investigating faculty decisions to adopt Web 2.0 technologies: Theory and empirical tests. The Internet and Higher Education, 11(2), 71- 80.

Alloway, T. \&Alloway, R. (2012). The impact of engagement with social networking sites (SNSs) on cognitive skills. Computers in Human Behavior, 28(5), 1748- 1754. 
Al-rahmi, W., Othman, M. \& Musa, M (2014). The Improvement of Students' Academic Performance by Using Social Media through Collaborative Learning in Malaysian Higher Education. Asian Social Science. Canadian Center of Science and Education, 10(8); 2014.

Al-Rahmi \& Othman (2013a).The impact of social media use on academic performance among university students: A pilot study. Journal of Information Systems Research and Innovation, 4(12).

Al-rahmi, W., \& Othman, M. (2013b). Using TAM model to measure the use of social media for collaborative learning. International J ournal of Engineering Trends and Technology (IJ ETT), 5(2).

Al-Rahmi \& Othman (2013c). Evaluating student's satisfaction of using social media through collaborative learning in higher education. International Journal of Advances in Engineering \& Technology, 6(4), pp. 1541-1551.

Al-rahmi, W. M. Othman, M.S. Yusof, L.M \& Musa. M.A. (2015a). Using social media as a tool for improving academic performance through collaborative learning in malaysian higher education. Review of European Studies, 7(3), p265.

Al-rahmi, W. M., Othman, M. S., \& Yusuf, L. M. (2015b). Social media for collaborative learning and engagement: Adoption framework in higher education institutions in malaysia. Mediterranean J ournal of Social Sciences, 6(3), 246.

Al-rahmi, W. M., Othman, M. S., \&Yusuf, L. M. (2015c). The effect of social media on researchers' academic performance through collaborative learning in malaysian higher education. Mediterranean J ournal of Social Sciences, 6(4), 193.

Annetta, L. A., Minogue, J ., Holmes, S. Y., \& Cheng, M. T. (2009). Investigating the impact of video games on high school students' engagement and learning about genetics. Computers \& Education, 53(1), 74-85.

Arnold, N., \& Paulus, T. (2010). Using a social networking site for experiential learning: Appropriating, lurking, modeling and community building. Internet and Higher Education,13(4), 188-196.

Banks, D. A. (2006). Reflections on the use of ARS with small groups. In D. A. Banks (Ed.), Audience response systems in higher education. Hershey, PA: Information Science Publishing.

Brown, S. (2012). Seeing Web 2.0 in context: A study of academic perceptions. The Internet and Higher Education, 15(1), 50- 57. 
Cao, Y., \&Hong, P. (2011). Antecedents and consequences of social media utilization in college teaching: A proposed model with mixed-methods investigation, 19(4), 297- 306.

Chen, Y. C. (2015). Linking learning styles and learning on mobile Facebook. The International Review of Research in Open and Distributed Learning, 16(2).

Chen, B., \& Bryer, T. (2012). Investigating instructional strategies for using social media in formal and informal learning. The International Review of Research in Open and Distributed Learning, 13(1), 87-104.

Cole, M. (2009). Using wiki technology to support student engagement: Lessons from the trenches. Computer \&Education, 52(1),141-146.

Cooper, R., \& Schindler,P. (2006). Marketing research. New York: McGraw- Hill.

Davis, F.D., Bagozzi, R.P. \&Warshaw, R.P. (1989).User acceptance of computer technology: a comparison of two theoretical models. J ournal of Management Science, 35(8), 982-1003.

Dawson, S. (2008). A study of the relationship between student social networks and sense of community. Educational Technology \& Society, 11(3), 224-238.

Ertmer, P., Newby, T., Liu, W., Tomory, A., Yu, J ., \& Lee, Y. (2011). Students' confidence and perceived value for participating in cross-cultural wiki-based collaborations. Educational Technology Research and Development, 59(2), 213- 228.

Eyrich, N., Padman, L., \& Sweetser, D. (2008). PR practitioners' use of social media tools and communication technology. Public Relations Review, 34(4), 412- 414.

Fewkes, A. M., \& McCabe, M. (2012). Facebook: Learning tool or distraction? J ournal of Digital Learning in Teacher Education, 28(3), 92-98.

Elsweiler,D., \& Harvey,M. (2014). Engaging and maintaining a sense of being informed: understanding the tasks motivating twitter search. J ournal of the American society for information science and technology, 66(2),264- 281.

Fornell, C., \& Larcker, D. F. (1998). Evaluating structural equation models with unob-servable variables and measurement error. J ournal of Marketing Research, 18(1), 39- 50.

Foroughi, A. (2011).A research framework for evaluating the effectiveness of implementations of social media in higher education. OnlineJ ournal for Workforce Education and Development, 5(1), 5. 
Friesen, N., \&Lowe, S. (2012). The questionable promise of social media for education: Connective learning and the commercial imperative. J ournal of Computer Assisted Learning, 28(3), 83-194.

Frye, E. M., Trathen, W., \& Koppenhaver, D. A. (2010). Internet workshop and blog publishing: Meeting student (and teacher) learning needs to achieve best practice in the twenty-firstcentury social studies classroom. Social Studies, 101(2), 46-53.

Gallini, S. M., \&Moely, B. E. (2003). Service-learning and engagement, academic challenge, and retention. Michigan J ournal of community Service Learning, 10(1).

Garrett, C., (2011). Defining, detecting, and promoting student engagement in college learning environments. Transformative Dialogues: Teaching \&Learning J ournal, 5(2), 1-12.

Hair, F., Black, C., Basin, J ., \&Anderson, E. (2010). Multivariate data Analysis. (7th ed.). New J ersey: Upper Saddle River, Pearson Prentice Hall.

Heafner, T. L., \& Friedman, A. M. (2008). Wikis and constructivism in secondary social studies: Fostering a deeper understanding. Computers in the Schools, 25(3-4), 288-302.

Hurt, N. E., Moss, G. S., Bradley, C. L., Larson, L. R., Lovelace, M. D., Prevost, L. B., \& Camus, M. S. (2012). The 'Facebook' effect: College students' perceptions of online discussions in the age of social networking. International J ournal for the Scholarship of Teaching and Learning, 6(2), 1-24.

J acobsen, W. C., \& Forste, R. (2011). The wired generation: Academic and social outcomes of electronic media use among university students. Cyberpsychology, Behavior, and Social Networking, 14(5), 275-280.

J ackson, C. (2011). Your students love social media ... and so can you. Teaching Tolerance, 39, 38-41. Retrieved from http:// www.tolerance.org/ magazine/ number-39-spring2011/your-students-love-social-media-and-so-can-you

J une, A. (2011).The effect of social network sites on adolescents' social and academic development: Current theories and controversies. J ournal of the American Society for Information Science and Technology, 62(8), 1435- 1445.

J unco, R. (2012). The relationship between frequency of Facebook use, participation in Facebook activities, and student engagement. Computers \&Education, 58(1), 162-171.

J unco, R., Heiberger, G. \& Loken, E. (2011) .The effect of Twitter on college student engagement and grades. J ournal of Computer Assisted Learning, 27(2), 119- 132. 
Kaplan, A. \& Haenlein, M. (2010).Users of the world, unite! The challenges and opportunities of social media. Business Horizons, 53(1), 59- 68.

Karpinski, A. (2009). A description of Facebook use and academic performance among undergraduate and graduate students. Annual Meeting of the American Educational Research Association, San Diego, California (pp.5-10).

Kim, B. (2011). Understanding antecedents of continuance intention in social-networking services. Cyberpsychology, Behavior and Social Networking, 14(4),199-205.

Kirschner, A., and Karpinski, C. (2010). Facebook and academic performance. Computers in Human Behavior, 26(6), 1237- 1245.

Kommers, P. (2011). Social media for learning by means of ICT. UNESCO Institute for Information Technologies in Education, UNESCO, Moscow, 1-10.

Krejcie, R.V., \& Morgan, D.W., (1970). Determining sample size for research activities. Educational and Psychological Measurement. 19(1), 43

Lamb, A., \& J ohnson, L. (2010). Bring back the joy: Creative teaching, learning, and librarianship. Teacher Librarian, 38(2), 61-66.

Lariscy, W., Avery, J ., Sweetser. D., \&Howes, P. (2009). An examination of the role of online social media in journalists' source mix. Public Relations Review, 35(3), 314- 316.

Larusson, J . \&Alterman, R. (2009).Wikis to support the 'collaborative' part of collaborative Learning. International J ournal of Computer-Supported Collaborative Learning, 4(4), 371-402.

Liu, C.-C., Liu, K.-P., Chen, W.-H., Lin, C.-P. \& Chen, G.-D. (2011). Collaborative storytelling experiences in social media: Influence of peer-assistance mechanisms. Computers \& Education. 57(2), 1544-1556.

Liu, Y. (2010). Social media tools as a learning resource. J ournal of Educational Technology Development and Exchange, 3(1), 101-114.

Liu, T. C., Liang, J . K., Wang, H. Y., Chan, T. W., \& Wei, L. H. (2003). Embedding educlick in classroom to enhance interaction. In Proceedings of International Conference on Computers in Education (ICCE), (pp. 117-125).

MacGeorge, E. L., Homan, S. R., Dunning, J . B., Elmore, D., Bodie, G. D., Evans, E., \& Lichti, S. M. (2008). The influence of learning characteristics on evaluation of audience response technology. J ournal of Computing in Higher Education, 19(2), 25-46. 
Madge, C., Meek, J ., Wellens, J ., and Hooley, T. (2009). Facebook, social integration and informal learning at university: It is more for socialising and talking to friends about work than for actually doing work. Learning, Media and Technology, 34(2), 141- 155.

Mazman, S. G., \& Usluel, Y. K. (2010). Modeling educational use of Facebook. Computers \& Education, 55(2), 444- 453 .

Meishar-Tal, H., Kurtz, G., \& Pieterse, E. (2012). Facebook groups as LMS: A case study. The International Review of Research in Open and Distributed Learning, 13(4), 33-48.

Meyer, K.A. (2010). A comparison of Web 2.0 tools in a doctoral course. Internet and Higher Education, 13(4), 226- 232.

McMillan, J ., \& Hwang, S. (2002). Measures of perceived interactivity: An exploration of the role of direction of communication, user control, and time in shaping perceptions of interactivity. J ournal of Advertising, 31(3), 29-42.

Moon.J \& Kim Y. (2001).Extending the TAM for a world-wide-web context. Information Management 38(4) 217- 230.

Naik, U., \& Shivalingaiah, D. (2008). Comparative study of web 1.0, web 2.0 and web 3.0.

Novak, E., Razzouk, R. \& J ohnson, T. (2012).The educational use of social annotation tools in higher education: a literature review. The Internet and Higher Education, 15(1), 39- 49.

O'Reilly, T. (2007).What is Web 2.0: design patterns and business models for the next generation of software. Communications and Strategies, 1(1), 17- 37.

Patera, M., Draper, S., \& Naef, M. (2008). Exploring magic cottage: A virtual reality environment for stimulating children's imaginative writing. Interactive Learning Environments, 16(3), 245-263.

Paul, A., Baker, M., \& Cochran, D. (2012). Effect of online social networking on student academic performance. Computers in Human Behavior, 28(6), 2117- 2127.

Pelling E \& White K . (2009).The theory of planned behavior applied to young people's use of social networking web sites. CyberPsychology \& Behavior , 12(6), 755-759.

Pike, G. R., Kuh, G. D., \& McCormick, A. C. (2011). An investigation of the contingent relationships between learning community participation and student engagement. Research in Higher Education, 52(3), 300-322. 
Rambe, P. (2008). Constructive disruptions for effective collaborative learning: Navigating the affordances of social media for meaningful engagement. Electronic J ournal of eLearning, 10(1), 132.

Roblyer, D., McDaniel, M., Webb, M., Herman, J., and Witty, V. (2010). Findings on Facebook in higher education: A comparison of college faculty and student uses and perceptions of social networking sites. The Internet and Higher Education, 13(3), 134- 140.

Redecker, C., Ala-Mutka, K., \& Punie, Y. (2010). Learning 2.0-The impact of social media on learning in Europe. Policy brief. J RC Scientific and Technical Report. EURJ RC56958 EN. Retrieved from http// bit. ly/ cljlpg

Sanchez , Cortijo \&J aved (2014).Students' perceptions of Facebook for academic purposes . Computers \&Education J ournal , 70, 138-149.

Shoshani, Y., \& Rose Braun, H. (2007). The use of the Internet environment for enhancing creativity. Educational Media International, 44(1), 17-32.

So, J ., \& Brush, T. (2008). Student perceptions of collaborative learning, social presence and satisfaction in a blended learning environment: Relationships and critical factors. Computers \& Education, 51(1), 318- 336.

Stevens, V. (2009). Modeling social media in groups, communities, and networks. Tesl-Ej, 13(3), 1-16.

Tomai, M., Rosa, V., Mebane, M. E., D’Acunti, A., Benedetti, M., \& Francescato, D. (2010). Virtual communities in schools as tools to promote social capital with high school students. Computers \&Education, 54(1), 265-274.

Top, E. (2012). Blogging as a social medium in undergraduate courses: Sense of community best predictor of perceived learning. Internet and Higher Education, 15(1), 24-28.

Turel, O., \& Serenko, A. (2012). The benefits and dangers of enjoyment with social networking websites. European J ournal of Information Systems, 21(5), 512-528.

Valjataga, T., \&Fiedler, S. (2009). Supporting students to self-direct intentional learning projects with social media. Educational Technology and Society, 12(3), 58-69.

Venkatesh, V. \& Bala, H. (2008).Technology acceptance model 3 and a research agenda on interventions. J ournal of Decision Sciences, 39(2), 273-315.

Venkatesh, V., Morris, M. G., Davis, G. B., \& Davis, F. D. (2003).User acceptance of information technology: Toward a unified view. MIS Quarterly, 27(3), 425-478. 
Vie, S. (2008). Digital divide 2.0:- Generation $\mathrm{m}$. and online social networking sites in the composition classroom. Computers and Composition, 25(1), 9- 23.

Vygotsky, L. S. (1978). Mind in society: The development of higher psychological processes. Cambridge, MA: Harvard University Press.

Wodzicki, K., Schwämmlein, E., \&Moskaliuk, J . (2012). Actually, I wanted to learn”: Studyrelated knowledge exchange on social networking sites. Internet and Higher Education, 15(1), 9-14.

Zixiu G, Xiongwen L., Yuan, L., \&Yifan, L. (2011). A framework of students' reasons for using cmc media in learning contexts: A structural approach. J ournal of the American society for information science and technology, 62(11):2182-2200.

(C) Al-Rahmi, Othman, and Yusuf

\section{Athabasca University $\mathbf{a}$}

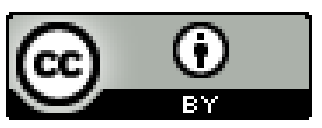

